\title{
Bentuk Lagu Dan Aransemen Paduan Suara Mars Jawa Timur
}

\author{
Gerald Adru Meyer \\ Program Studi Musik Fakultas Bahasa dan Seni Universitas Negeri Surabaya \\ e-mail: geraldmeyer86@gmail.com / geraldmeyer.mhs@unesa.ac.id
}

\begin{abstract}
Jawa Timur Mars song is the result of a process of music in the form of a song that became an identity for the people of East Java, which was introduced in 2018 during the commemoration of the 73 rd anniversary of East Java Province. This Mars was introduced with a nationalist spirit with the hope of further strengthening the unity of every society. This article will discuss the form of songs and arrangements in the composition of the four choirs that have been studied using the method of music form analysis that can provide an alternative in providing an explanation of the song in the form of mars.
\end{abstract}

Keywords: Jawa Timur Mars, Song Form, Arrangement

Abstrak: Lagu Mars Jawa Timur hasil dari proses karya musik berupa lagu yang menjadi identitas bagi masyarakat Jawa Timur yang mulai diperkenalkan pada tahun 2018 pada saat peringatan HUT Provinsi Jawa Timur yang ke-73. Mars ini diperkenalkan dengan sebuah semangat nasionalis dengan harapan semakin mempererat kesatuan setiap masyarakat. Dalam artikel ini akan dibahas bentuk lagu dan aransemen pada susunan paduan empat suara yang telah diteliti dengan menggunakan metode analisis bentuk musik yang dapat memberikan sebuah alternatif dalam memberikan penjelasan terhadap lagu berbentuk mars.

Kata kunci: Mars Jawa Timur, Bentuk Lagu, Aransemen

\section{PENDAHULUAN}

Musik mars adalah salah satu jenis musik dengan irama teratur dengan tempo orang berjalan hingga cepat, dan memberikan kesan yang tegas. Lagu mars dapat ditulis dalam birama $2 / 4,4 / 4$, tetapi terkadang dalam birama $6 / 8$, atau 2 (genap) x $3 / 8$ dengan tempo cepat (Simanungkalit, 2008:77-78). Sebagai bentuk identitas dalam mewujudkan eksistensi keberadaan suatu lembaga atau insitusi yang bersifat komunal dinyatakan melalui pengaplikasian ilmu pengetahuan seni dalam bentuk proses karya penciptaan seni. Salah satunya dalam mewujudkan ekspresi tersebut dinyatakan melalui karya seni dapat berupa musik, lukisan, dan lain sebagainya. Dalam hal ini suatu lembaga atau institusi memiliki sebuah identitas yang diwujudkan melalui karya lagu, mars Jawa Timur diciptakan dengan sebuah maksud dan tujuan dalam menggambarkan keberagaman budaya yang ada serta mempersatukan masyarakat dalam perbedaan yang ada.

Mars Jawa Timur sebagai perwakilan yang diharapkan dapat memberikan sebuah gambaran atau icon bagi eksistensi masyarakat. Mars ini diciptakan oleh karena semangat nasionalis yang digambarkan dalam bentuk syair atau lirik yang kemudian diberi susunan nadanada membentuk melodi, dan disebut sebagai lagu yang utuh. Sejarah dalam penciptaan karya mars ini ingin memberikan semangat yang dituangkan bagi seluruh masyarakat Jawa Timur oleh mantan gubernur bernama Dr. H. Soekarwo, S.H., M.Hum., yang selanjutnya aransemen dalam bentuk paduan empat suara oleh Ferry Kristanto yang juga adalah Aparatur Sipil Negara (ASN) berasal dari kota Tulungagung.

Dengan adanya mars Jawa Timur semangat yang ingin ditularkan dapat memberikan sebuah penilaian terhadap kehidupan bermasyarakat yang lebih baik dan menjadi peringatan dengan kemajemukan Jawa 
Timur sebagai bagian dari Negara Kesatuan Republik Indonesia (NKRI). Semangat inilah yang muncul melalui bentuk lagu dan aransemen yang diharapkan dapat memberikan pandangan bagi masyarakat secara umum serta setiap aparatur negara dalam mengemban tugas yang dikerjakan dimasing-masing lembaga atau institusi.

Dalam proses pengenalan lagu mars Jawa Timur bagi masyarakat dan ASN secara khususnya dilakukan beberapa langkah dengan me-launching pada HUT peringatan ke-73 tahun 2018 dan memberlakukan di beberapa lembaga instansi untuk dinyanyikan pada pelaksanaan upacara, serta memilih lagu mars Jawa Timur sebagai lagu wajib dalam pelaksanaan lomba paduan suara untuk tingkat regional.

\section{METODE ANALISIS}

Metode penelitian pada dasarnya merupaka cara ilmiah untuk mendapatkan data dengan tujuan dan kegunaan tertentu (sugiyono, 2013:3). Deskriptif analisis merupakan suatu metode penelitian yang mengungkapkan tentang obyek dalam bentuk deskriptif yang disertai analisis terhadap segala sesuatu melalui pendekatan yang telah ditentukan.

Bentuk penelitian ini Analisis Lagu. Menganalisis lagu dapat dipahami sebagai bentuk dalam menguraikan komponen-komponen pembentuk lagu tersebut. Komponen di sini bisa diartikan sebagai unsur pembentuk lagu. Aaron Coplan (1939:33) mengungkapkan bahwa unsurunsur musik meliputi: melodi, ritme, harmoni, dan timbre (warna bunyi)". Mentranskripsikan unsur-unsur musik pada dasarnya adalah mengalihkan unsur-unsur tersebut dari bentuk audio ke dalam bentuk visual atau tulisan". Penggunaan dua proses transkripsi merupakan pendekatan yang penting, dengan membuat analisis sementara serta mendeskripsikan apa yang kita dengar kemudian menuliskannya diatas kertas (tentang musik yang didengar) dan mendeskripsikan apa yang kita lihat dan dengar tersebut, hal ini disebut sebagai proses dalam pengumpulan data. Hasil dari pengumpulan data tersebut kemudian divalidasi dengan teknik validitas data berupa wawancara, dan metode triangulasi.

\section{PEMBAHASAN \\ Bentuk Lagu}

Mars Jawa Timur memiliki 27 birama dengan terbagi menjadi 3 liedform atau bait yaitu A, B, dan C. Masing-masing bait memiliki 4 motif.

\section{Bait 1}

Pada bait pertama atau diuraikan menurut kelompok A dan B pada birama 1-8 motif disebut dengan motif $\mathrm{X}_{\mathrm{n}}$, dalam uraian analisa berikut bentuk frase diuraikan sebagai kalimat tanya (antecendent) atau kalimat jawa (consequent).

Kutipan Lirik:

Satukan langkah Jawa Timur jaya

Membangun masyarakat aman sejahtera

Gotong Royong dasar semangatnya

Adil makmur berakhlak mulia tujuannya

\section{Kelompok A}

Motif $X_{1}$ dan $X_{2}$ (birama 1-4)

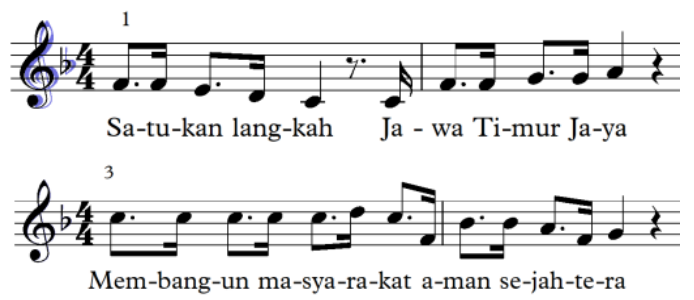

Pada bagian ini motif $\mathrm{X}_{1}$ terdapat pada birama 1-2 dengan progresi akord I, dan motif $\mathrm{X}_{2}$ pada birama 3-4 dengan prograsi akord I - V merupakan frase dengan jenis kalimat tanya

\section{Motif $\mathrm{X}_{3}$ dan $\mathrm{X}_{4}$ (birama 5-8)}

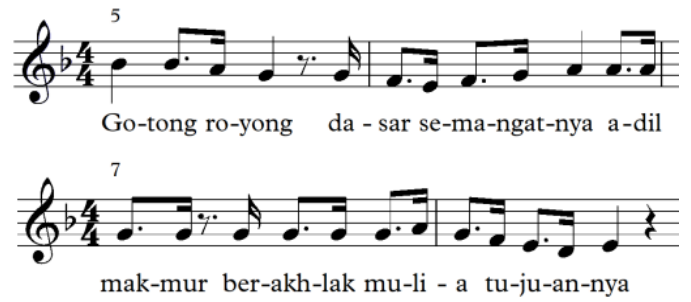

Pada bagian ini motif $X_{3}$ terdapat pada birama 5-6 dengan progresi akord ii - I, dan motif $\mathrm{X}_{4}$ pada birama 7-8 dengan progrsi akord II - V merupakan frase dengan jenis kalimat tannya

\section{Bait 2}

Pada bait kedua atau kelompok B birama 9-16 motif disebut dengan motif $\mathrm{Y}_{\mathrm{n}}$, dalam uraian 
analisa berikut bentuk frase diuraikan sebagai kalimat tanya (antecendent) atau kalimat jawa (consequent).

Kutipan Lirik:

Pelayanan prima tugas dipundak kita

Jalan menuju masyarakat sejahtera

Kobarkan semangat layani masyarakat

Parasamya purnakarya nugraha hasilnya

\section{Kelompok B}

Motif $Y_{1}$ dan $Y_{2}$ (birama 9-12)
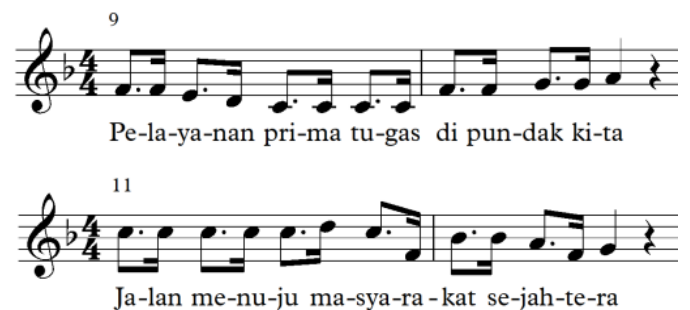

Pada kelompok B motif $Y_{1}$ terdapat pada birama 9-10 dengan progresi akord I, dan motif $\mathrm{Y}_{2}$ pada birama 11-12 dengan progresi akord $\mathrm{I}-\mathrm{ii}-\mathrm{V}_{7}$

\section{Motif $Y_{3}$ dan $Y_{4}$ (birama 13-16)}
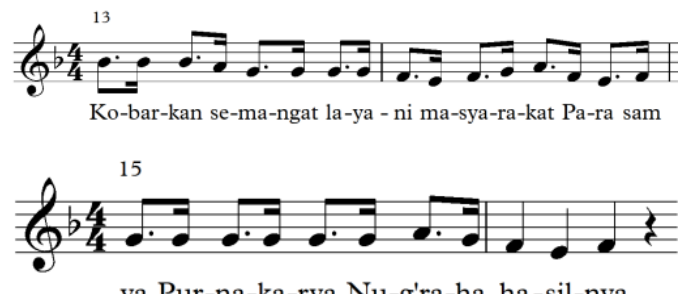

ya Pur-na-ka-rya Nu-g'ra-ha ha-sil-nya

Pada bagian ini motif $\mathrm{Y}_{3}$ terdapat pada birama 13-14 dengan progresi akord ii - V - I, dan motif $\mathrm{Y}_{4}$ pada birama 15-16 dengan progresi akord $\mathrm{V}-\mathrm{I}-\mathrm{V}_{7}-\mathrm{I}$ merupakan frase dengan jenis kalimat jawab

Bait 3

Pada bait ketiga atau kelompok $\mathrm{C}$ birama 17-27 motif disebut dengan motif $\mathrm{Zn}$, dalam uraian analisa berikut bentuk frase diuraikan sebagai kalimat tanya (antecendent) atau kalimat jawa (consequent).

Kutipan Lirik:

Majulah Jawa TImu bumi Majapahit

Musyawarah, mufakat budayanya

Rakyatnya pekerja keras luar biasa

Pancasila pandangan hidupnya

Jayalah, Jawa Timurku!

Kelompok C

Motif $Z_{1}$ dan $Z_{2}$ (birama 17-20)
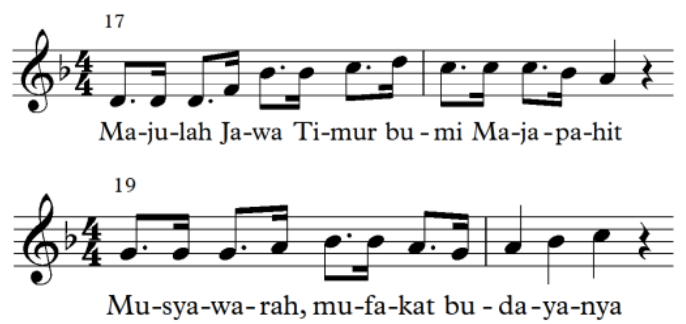

Pada kelompok C motif $Y_{1}$ terdapat pada birama 17-18 dengan progresi akord IV - I, dan motif $\mathrm{Y}_{2}$ terdapat pada birama 19-20 dengan progresi akord V - I merupakan frase dengan kalimat jawab

Motif $Z_{3}$ dan $Z_{4}$ (birama 21-27)

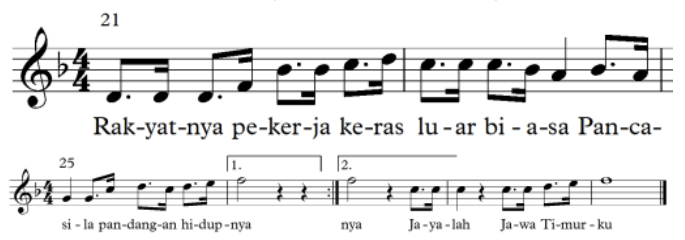

Penguraian pada motif $Z_{3}$ terdapat pada birama 21-22 dengan progresi akord IV - I, dan motif $\mathrm{Z}_{4}$ terdapat pada birama 23-24 dengan progresi akord V - I. Didapati analisa pada birama 25 yang merupakan pengulangan sebagai kamar II dan diakhiri dengan sebuah kadens atau akhiran kalimat sebagai penutup pada birama 2627.

\section{Aransemen}

Menurut Genichi Kawagami teori aransemen dalam bukunya yang berjudul Popular Aranging Music: A Practical Guide menyebutkan beberapa aspek atau hal yang dianggap perlu diperhatikan bahwa sebuah karya lagu atau musik itu mengalami proses aransemen diantaranya ialah:

1) Melodic Variation and Fake;

2) Rhytmic Variation and Fake;

3) Obligato;

4) Filler; dan

5) Counter Melody

Pada lagu mars Jawa Timur, aransemen yang telah dianalisa hanya berfokus pada Melodic Variation and Fake, Rhytmic Variation and Fake. Hal tersebut terjadi pada pembagian suara alto dan bass, sedangkan suara tenor atau suara tiga sama persis dengan smelodi utama yaitu suara sopran. Dalam analisa yang telah dilakukan didapati bahwa aransemen ini berfokus pada penggunaan harmoni dengan sifat harmoni 
tertutup, yaitu tidak memungkinkan lagi untuk menyisipkan nada harmonis dalam susunan paduan suara.

\section{Sopran}

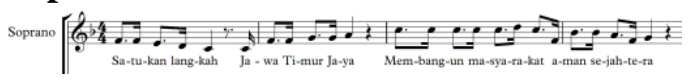

Section sopran sebagai melodi utama dalam penentuan dan penyusunan pembagian suara section alto dan bass:

Alto

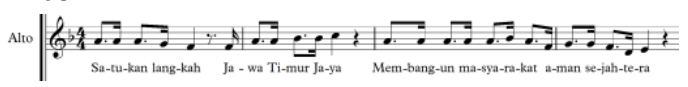

Section alto sebagai counter melody terhadap melodi utama dengan jarak ters dari melodi utama

\section{Tenor}

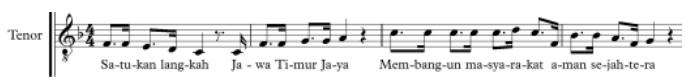

Section tenor dalam susunan pembagian suara tidak mengalami aransemen berupa Melody Variaton and Fake, dalam analisa didapati bahwa section tenor saja yang sama persis dengan section sopran atau melodi utamanya

\section{Bass}

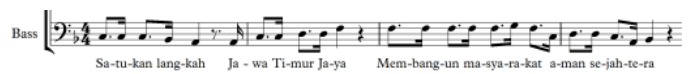

Section bass dalam susunan pembagian suara mengalami aransemen berupa Melody Variation and Fake, dalam analisia didapati bahwa section bass melodi bergerak mengikuti tatanan pada suara sopran dengan jarak kuint dibawah melodi utama

\section{Pola Irama}

Dalam mars ini, pola irama tidak dapat dipisahkan dengan penggunaan jenis ritmis bergaya mars dengan nilai nada $1 / 8$ dan $1 / 16$, dengan tempo allegro. Penggunaan nilai ritmis dan jenis tempo allegro yang merupakan penggambaran dari salah satu bentuk semangat derap langkah tentara pada saat berjalan. Pola irama inilah yang terdapat dari motif yang ada pada gaya mars yang dimiliki oleh mars Jawa Timur. Berikut kutipan pola irama yang ada pada lagu ini dalam menggambarkan pola bergaya mars:

\section{Pola Irama 1}

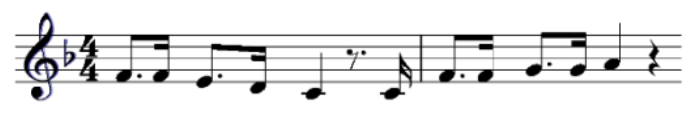

Terdapat pengembangan pola irama 1 ini yang terjadi pada motif $\mathrm{Y}_{1}$. Pengembangan ini terjadi dalam bentuk pengecilan nilai nada atau dengan istilah lain yaitu Diminuation of the Value sebagai berikut,

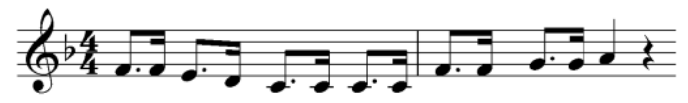

Pola Irama 2

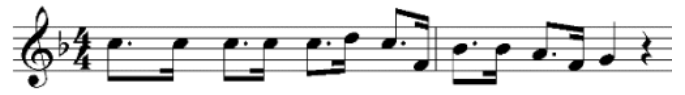

Pengembangan pola irama juga terjadi pada pola irama 2 ini yang terjadi pada motif $\mathrm{Y}_{3}$ dalam bentuk pengecilan nilai nada sebagai berikut,

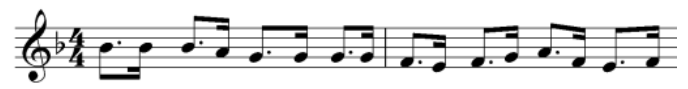

\section{Pola Irama 3}

Dalam pola irama ini terjadi sebanyak dua kali terdapat pada birama 3-4 dan 11-12 yang diulang secara harafiah atau dengan sebutan lain Repetition sebagai berikut,

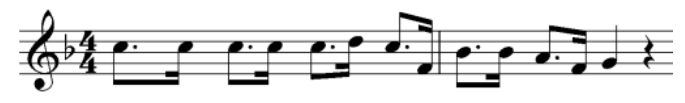

Pola irama yang terdapat pada mars ini diikuti dengan pergerakan melodi atau alur melodi yang tersusun dari beberapa nada menjadi sebuah susunan yang baik menentukan jenis akor yang mempengaruhi bentuk dan karakter suara dalam paduan empat suara.

\section{Alur Melodi}

Pergerakan nada atau dalam uraian ini akan dijelaskan berkaitan dengan alur melodi. Alur melodi ini didasarkan dari pengertian pergerakan nada-nada yang telah ada dan disusun sedemikian rupa dengan teknik harmoni. Dalam buku Ilmo Harmoni, karya Prier disebutkan empat teknik bentuk pergerakan atau pola gerakan nada, diantaranya gerakan yang sejajar, gerakan yang lurus atau searah, gerakan ke samping dan gerakan yang berlawanan. Dalam analisa yang telah dilakukan pada partitur mars Jawa Timur, didapati pergerakan nada dalam teknik harmoni terdapat pada pembagian suara alto, tenor dan bass ini bergerak secara sejajar terhadap melodi utama yaitu pada suara sopran. Lagu mars ini mengalami pergerakan secara sejajar yang terjadi pada birama 1 hingga 27 
secara penuh. Untuk memberikan sebuah pemahanan tentang pergerakan melodi yang sejajar berikut ilustrasi notasi pergerakan melodi yang sejajar:

Uraian ini, akan menjelaskan bentuk pergerakan alur melodi sejajar yang terdapat pada Tail in bait 1 dan bait 2 sebagai beikut,

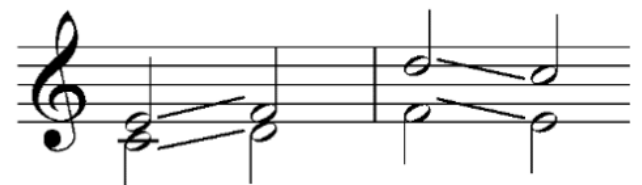

Alur melodi sejajar pada Tail in bait 1

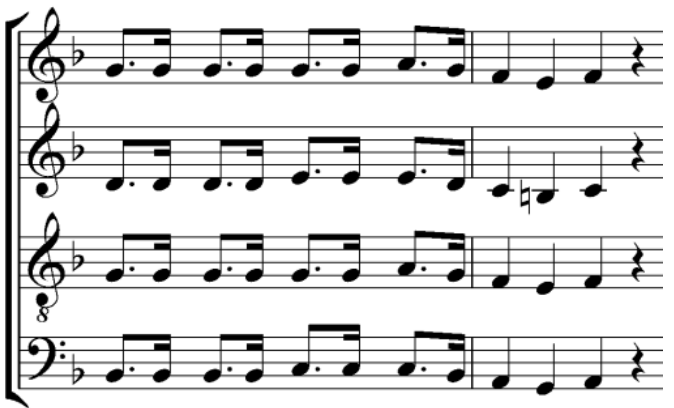

Alur melodi sejajar pada Tail in bait 2

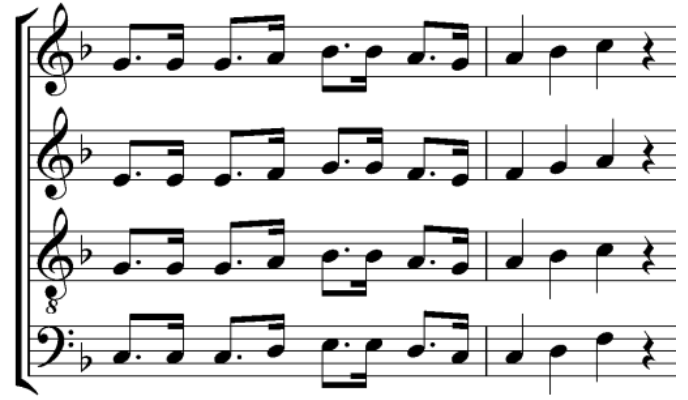

Harmoni

Penggunaan harmoni dalam tatanan paduan suara menentukan enak dan tidak enaknya karya tersebut. Dalam buku yang berjudul Ilmu Harmoni karya Prier disebutkan bahwa dalam tatanan paduan suara format paduan empat suara dengan gabungan vokal pria dan wanita merupakan harmoni yang paling lengkap atau dengan kata lain paling baik.

Harmoni pada lagu mars ini menggunakan bentuk inversi akor dengan mengacu pada nada melodi utama yang terdapat dalam range suara sopran. Penggunaan teknik harmoni pada lagu ini bersifat harmoni tertutup, dimana harmoni tertutup ini memberikan pemahaman berkaitan dengan tidak memungkinkan lagi untuk memasukkan nada harmonis dalam tatanan pembagian empat suara (S-A-T-B). Penggunaan teknik harmoni, inversi akor yang terjadi bersifat inversi pada susunan tonika mayor $(\mathrm{T})$ dan minor $(\mathrm{t})$, subdominan $(\mathrm{S})$ mayor dan minor (s), serta dominan $7_{\text {th }}\left(\mathrm{D}_{7}\right)$.

Berikut uraian penggunaan inversi akor dalam motif $X_{1}-X_{2}$, dan $X_{3}-X_{4}$ yang menggunakan akor terts tonika mayor $\left(\mathrm{T}_{5}\right)$ dan tonika (T), subdominan (s5), dan jatuh pada akor dominan seven $\left(\mathrm{D}_{7}\right)$ dan dilanjutkan penggunaan inversi akor pada motif $\mathrm{X}_{3}$ dan $\mathrm{X}_{4}$, dengan menggunakan akor kwint subdominan (s5), terts subdominan (s3), tonika mayor kwint ( $\left.\mathrm{T}_{5}\right)$ dan jatuh pada inversi II akor dominan (Ds).

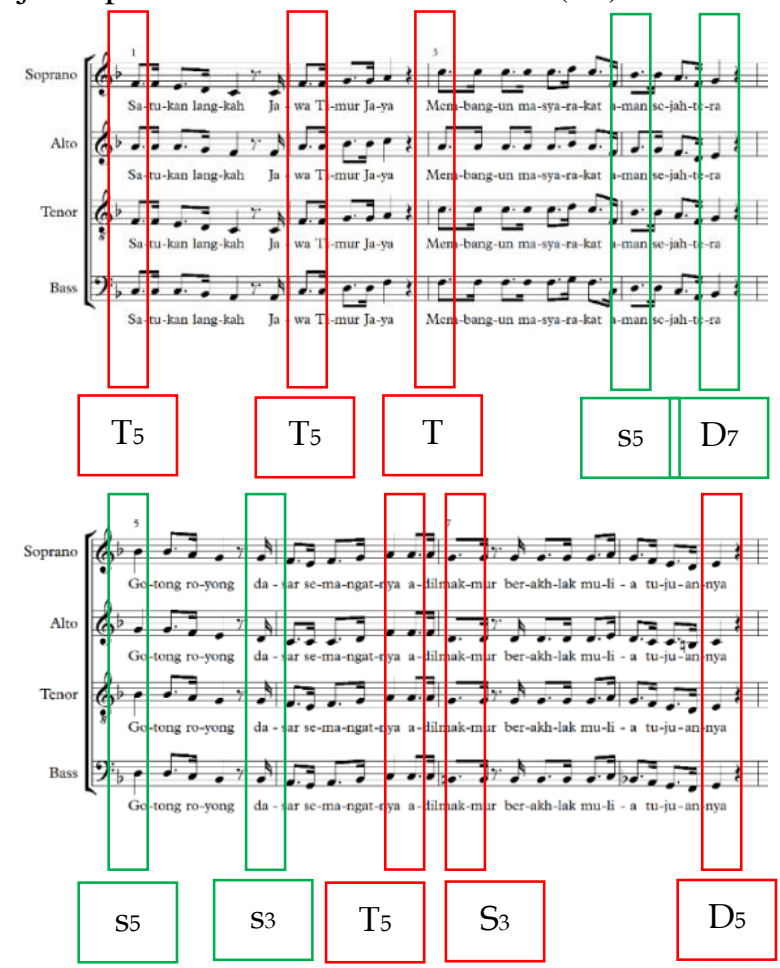

Penggunaan inversi akor selanjutnya pada motif $\mathrm{Y}_{1}-\mathrm{Y}_{2}$ dan $\mathrm{Y}_{3}-\mathrm{Y}_{4}$ dengan progresi akor mayor tonika dengan kwint bass (T5), diulang kembali pada tonika kwint, akor tonika (T), subdominan (s5), jatuh pada inversi II akor terts dominan $\left(\mathrm{D}_{3}\right)$ dan pada motif $\mathrm{Y}_{3}-\mathrm{Y}_{4}$ menggunakan inversi akor minor subdominan kwint (s5), tonika dengan terts sebagai bass $\left(\mathrm{T}_{3}\right)$, akor subdominankwint (s5), tonika terts $\left(\mathrm{T}_{3}\right)$, dominan kwint (D5) dan berakhir pada akor tonika terts $\left(\mathrm{T}_{3}\right)$. 

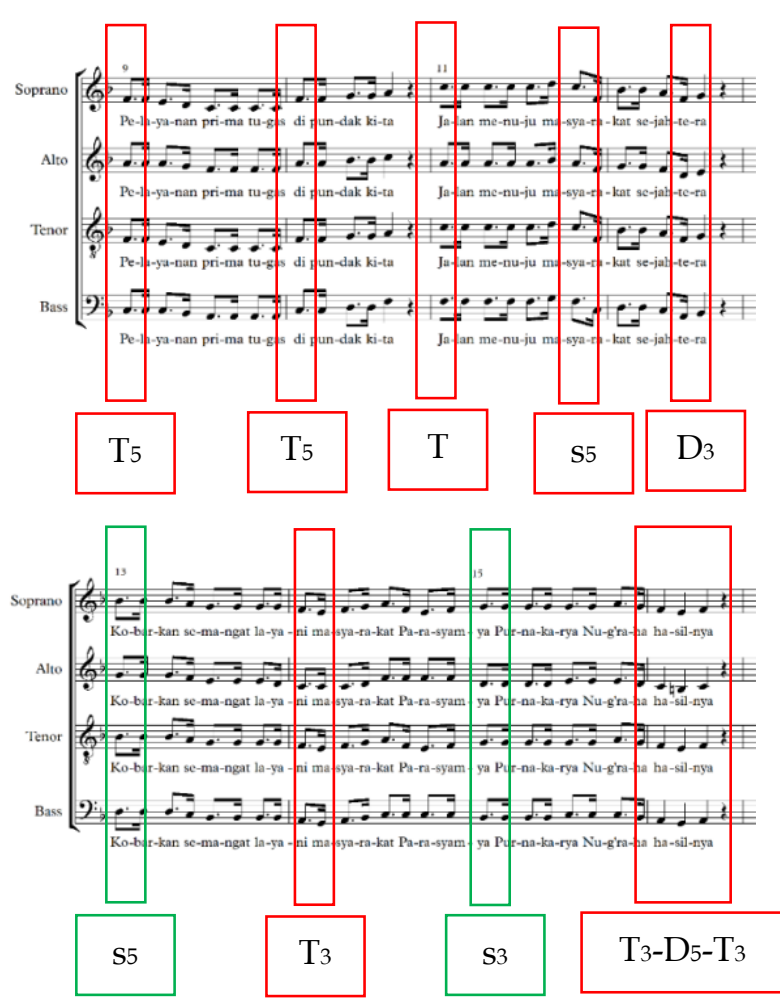

Selanjutnya penggunaan inversi akor selanjutnya pada motif $Z_{1}-Z_{2}$ dan $Z_{3}-Z_{4}$. Dalam pembahasan ini terlihat perbedaan dalam penggunaan harmoni pada motif $\mathrm{Z}_{1}$ dan $\mathrm{Z}_{2}$ merupakan jenis unison dengan progresi akor IV$\mathrm{I}-\mathrm{V}-\mathrm{I}$ dengan menggunakan inversi akor dominan (D) dan akor tonika kwint sebagai bass ( $\mathrm{T}_{5}$ ). Dan dilanjutkan dengan inversi akor pada motif $\mathrm{Z}_{3}-$ $\mathrm{Z}_{4}$ dengan diawali penggunaan harmoni yang bersifat unison dan dilanjutkan penggunaan akor dominan (D), akor tonika terts sebagai bass ( $\left.\mathrm{T}_{3}\right)$ dan dominan kwint berakhir pada akor tonika terts $\left(\mathrm{T}_{3}\right)$.

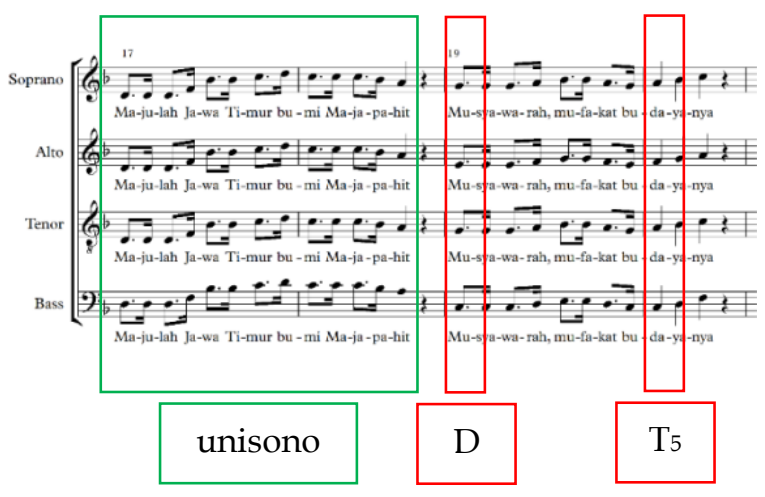

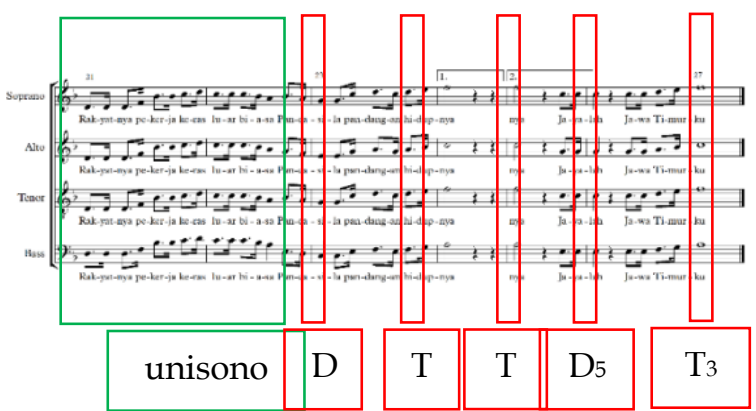

\section{PENUTUP}

Dalam artikel ini memberikan pemahaman ringkas tentang kajian bentuk lagu dan aransemen Mars Jawa Timur yang diciptakan oleh mantan Gubernur Jawa Timur Dr. H. Soekarwo, S.H., M.Hum., yang diaransemen oleh Ferry Kristanto. Hasil dari penelitian ini menunjukkan proses penciptaan lagu bergaya mars dengan 27 birama yang memiliki bentuk lagu tiga bagian dan aransemen paduan empat suara pada section alto dan bass, sedangkan section tenor sama persis dengan melodi utamanya yaitu sopran.

Dalam analisis yang dilakukan, menurut buku Popular Aranging Populer Music: A Practical Guide teori aransemen menurut Kawagami yang digunakan hanya terjadi pada Melody Variation and Fake sebagai harmoni yang diatur sedemikian rupa terhadap susunan empat suara.

\section{DAFTAR PUSTAKA}

Banoe, Pono. 2003. Pengantar Pengetahuan Harmoni. Yogyakarta: Kanisius

Banoe, Pono. 2011. Kamus Musik. Yogyakarta: Kanisius

Isfanhari, Musafir dan Nugroho, Widyo. 2002. Pengetahuan Dasar Musik. Surabaya: Dinas P dan K Propinsi Daerah Tk. I Jawa Timur

Karyawanto, H. Y. (2018). BENTUK LAGU DAN AMBITUS NADA PADA ORKESTRASI MARS UNESA. Virtuoso (Jurnal Pengkajian dan Penciptaan Musik), 1(1), 8-14.

Kawakami, Genichi. 1975 Aranging Populer Musik: A Protical Guide, Tokyo: Yamaha Music Fondation 
Prier, Karl Edmun. 2014. Ilmu Harmoni.

Yogyakarta: Pusat Musik Liturgi

Prier, Karl Edmun. 2014. Kamus Musik.

Yogyakarta: Pusat Musik Liturgi

Prier, Karl Edmun. 1996. Ilmu Bentuk Musik.

Yogyakarta: Pusat Musik Liturgi 